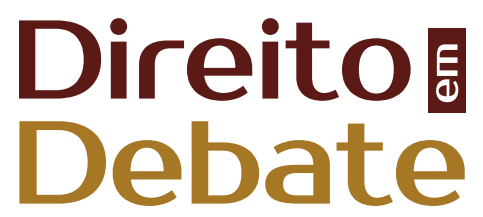

Revista do Departamento de Ciências Jurídicas e Sociais da Unijuí Editora Unijuí - Ano XXX - n. 55 - jan./jun. 2021 - ISSN 2176-6622

\title{
O ATIVISMO JUDICIAL: Ruptura à Democrática Representatividade Política Brasileira?
}

\author{
http://dx.doi.org/10.21527/2176-6622.2021.55.242-251
}

Recebido em: 28/2/2020

Modificações solicitadas em: 20/4/2020

Aceito em: 7/6/2020

Mário Lúcio Quintão Soares
Pontifícia Universidade Católica de Minas Gerais. Belo Horizonte/MG, Brasil.

Ana Luiza Novais Cabral

Autora correspondente. Pontifícia Universidade Católica de Minas Gerais. Av. Dom José Gaspar, 500 - Coração Eucarístico. CEP 30535-901. Belo Horizonte/MG, Brasil. http://lattes.cnpq.br/2623437173992273. https://orcid.org/0000-0002-3051-2328. anamutum@hotmail.com

\section{RESUMO}

O ativismo judicial é considerado de alta relevância e complexidade na contemporaneidade do direito brasileiro. De tais conjecturas e discussões extrai-se inúmeros casos emblemáticos ativistas proferidos pelo Poder Judiciário. Em contrapartida, o apontamento constante do ativismo judicial encontra-se diretamente relacionado a uma crise de representatividade política que se afere por meio de uma inércia e/ ou omissão dos poderes políticos, qual seja, Poderes Legislativo e Executivo. Assim, utilizando-se de uma metodologia teórico-jurídico com raciocínio dedutivo, mediante análise doutrinária e jurisprudencial serão observados importantes fatores que influenciaram diretamente no enaltecimento do Poder Judiciário por intermédio do ativismo judicial, conferindo uma ruptura à representatividade política democraticamente garantida pela Constituição Federal brasileira.

Palavras-chave: Ativismo judicial. Expansão do Poder Judiciário. Poderes políticos. Democracia. Representatividade política.

\section{JUDICIAL ACTIVISM: BREAKS DEMOCRATIC BRAZILIAN POLITICAL REPRESENTATIVITY?}

\section{ABSTRACT}

Judicial activism is considered of high relevance and complexity in the contemporaneity of Brazilian law. From such conjectures and discussions, many emblematic activist cases have been extracted by the Judiciary. On the other hand, the constant observation of judicial activism is directly related to a crisis of political representativeness that is affected by an inertia and/or omission of the political powers, that is, Legislative and Executive Powers. Thus, using a theoretical-juridical methodology with deductive reasoning, through doctrinal and jurisprudential analysis will be observed important factors that directly influence the enhancement of the Judiciary through judicial activism conferring a rupture the political representation democratically guaranteed by the Brazilian Federal Constitution.

Keywords: Judicial activism. Expansion of the Judiciary. Political powers. Democracy. Political representativeness.

\section{SUMÁRIO}

1 Introdução. 2 Aspectos técnicos e formais do ativismo judicial brasileiro. 3 A representatividade política no direito brasileiro como garantismo democrático. 40 ativismo judicial: ruptura à democrática representatividade política brasileira? 5 Considerações Finais. 6 Referências. 


\section{INTRODUÇÃO}

A proeminente participação ativa do Poder Judiciário em matérias decisórias de cunho politicamente legislativas tem se tornado corriqueiramente perigosa com a intromissão constante de um poder perante o outro. Diante do evento atual descrito, cumulado com uma crise representativa, o Poder Judiciário é provocado a decidir sobre assuntos de alçada que, em sua forma real, não são de sua competência, tendo em vista haver o Poder Legislativo e Executivo atributos para tal.

Sobre o argumento disposto, é cabível deliberar sobre o tema e as diversas decisões ativistas que surgem repetidamente em jurisprudências brasileiras. A proliferação constante do Ativismo Judicial acaba por realçar, de forma altamente proeminente, o status majoritário do Poder Judiciário em contrapartida aos outros Poderes. A interferência não é considerada prejudicial quando garante necessidades básicas do povo e concretiza o andamento legal com o anseio geral, porém deve ser observada de forma excepcional, tendo em vista que os direitos devidos deveriam ser concretizados pela participação do Poder Legislativo, que representa politicamente o povo no regime democrático de direito.

Nesse contexto se faz um paralelo entre ativismo judicial e a crise de representatividade política garantida pela Constituição Federal, colocando aspectos diversos sobre as doutrinas atuais e sua quebra de paradigma da velada separação de poderes.

Ademais, deve-se inferir que o ativismo judicial é um fato, e não somente uma mera suposição doutrinária. O Poder Judiciário, por intermédio do Supremo Tribunal Federal, tem atuado proativamente em detrimento dos outros Poderes, inovando de forma criativa e ultrapassando sua esfera de julgador no papel de legislador positivo. Inúmeros são os casos concretos em que o órgão agiu de tal forma e o faz com o intuito de possibilitar que as normas acompanhem as súplicas sociais.

Desta maneira, é necessário fazer uma correlação entre o ativismo judicial - sua inovação normativa - diretamente com uma representatividade política apática e omissa. Como o Poder Judiciário não pode se negar a julgar, matérias complexas de atribuições legislativas são levadas a ele na busca de solução.

A representatividade ineficiente, no entanto, é um fator educacional, tendo em vista que os representantes do povo são eleitos por voto popular. Não obstante, portanto, o ativismo judicial seja uma salvaguarda da população, ele só existe em razão de um poder político apático que é influência direta da crise democrática e informacional.

Assim, o presente artigo inicia com a desmistificação do ativismo judicial brasileiro, seu conceito, técnica e forma, atribuindo ao mesmo os pontos positivos e negativos descritos na doutrina atual. Seguindo, o texto apresenta aspectos sobre a representatividade política brasileira, a crise atual com suas causas, consequências e a convergência entre a representatividade política com a descrença na democracia. Por fim, o artigo aborda como o ativismo judicial possui um engrandecimento por meio de uma representatividade inerte e desregular.

A metodologia utilizada para apresentação do problema é a teórico-jurídico com raciocínio dedutivo, tendo como sua quebra de paradigma a correlação entre as notáveis e crescentes decisões ativistas com uma alta crise na representatividade política brasileira.

\section{ASPECTOS TÉCNICOS E FORMAIS DO ATIVISMO JUDICIAL BRASILEIRO}

Na fase do neoconstitucionalismo brasileiro na Constituição Federal de 1988, com seus princípios basilares e garantias fundamentais, o Poder Judiciário passa de um órgão totalmente técnico entrando na esfera política. A redemocratização, vista com as características dispostas na Constituição, abre espaço para a população pleitear seus direitos sociais com uma postura mais dinâmica e assistencialista. Da mesma forma que o país possui um exacerbado positivismo, os operadores jurídicos são chamados a saírem do seu tecnicismo entrando em questões que deveriam ser solucionadas pelos órgãos políticos dadas suas atribuições diretas (típicas) ou primárias.

O ativismo judicial é uma espécie da judicialização da política, sendo descrito como "uma atitude, ou seja, a escolha de um modo específico e proativo de interpretar a Constituição, expandindo o seu sentido e alcance" (ABREU, 2013, p. 140). Esse autor, sobre o tema, relata que, "enfim, podemos concluir que o ativismo judicial se mostra como a ampliação do poder dos tribunais no controle dos demais poderes, pelo viés constitucional" (p. 142). 
Não obstante o ativismo judicial seja encontrado com maior facilidade na Corte Suprema, o instituto pode ser visto também em outras instâncias, embora menos frequentes. Nos ensinamentos, Ricardo Vieira de Carvalho Fernandes dispõe que o ativismo judicial pode ser dividido em judicial ou extrajudicial, posto que "o primeiro é realizado na prestação jurisdicional dos magistrados, sobretudo da Corte Constitucional"; Fernandes (2012) continua relatando que "o segundo, refere-se à forma como os magistrados se portam perante os demais Poderes, a sociedade e a opinião pública, como, por exemplo, quando concedem entrevistas, discursos e outras formas de pronunciamento externo ao processo" (p. 106).

O fenômeno do ativismo judicial é tema atual e de constantes discussões jurídico-filosóficas, em que tendem a se instalar quando o Poder Legislativo, órgão típico na atribuição da promulgação das leis, se mostra inerte ou omisso perante a sociedade quando a mesma clama por mudanças ou inovações normativas. Quando o Poder Legislativo ignora algumas questões que a sociedade civil necessita alterar, o Poder Judiciário é provocado a decidir, e, não podendo se eximir, acaba inovando na ordem jurídica e legislativa sobre tal assunto.

O que ocorreu e o que vem ocorrendo em terrae basilis: as decisões dos Tribunais são proferidas de acordo com a visão de cada componente, soçobrando, com isso, a legislação e, o que é pior, a Constituição. Sob pretexto de o juiz não ser mais o "juiz boca da lei" (positivismo primitivo), agora temos o juiz (tribunal), para quem (para qual) a lei é apenas - como diriam alguns doutrinadores adeptos de teorias voluntaristas - a ponta o iceberg. E, por vezes, nem mesmo isso...! No fundo, volta-se ao velho positivismo fático, versão voluntarista do realismo jurídico: a lei é aquilo que os Tribunais dizem que é (como que a repetir a famosa frase do juiz Oliver Holmes) (STRECK, 2013, p. 314).

Nas ideias de Luís Roberto Barroso, o ativismo judicial manifesta-se com as seguintes características: a) "a aplicação direta da Constituição a situações não expressamente contempladas em seu texto e independentemente de manifestação do legislador ordinário"; b) "a declaração de inconstitucionalidade de atos normativos emanados do legislador, com base em critérios menos rígidos que os de patente e ostensiva violação da Constituição"; e c) "a imposição de condutas ou de abstenções ao Poder Público, notadamente em matéria de políticas públicas" (BARROSO, 2019, p. 6).

O ativismo judicial é caracterizado em dois aspectos: quando invade a esfera do poder legislativo e proativamente inova no ordenamento jurídico, retirando do cidadão o seu direito democrático de ser representado por aquele que elegeu, e quando o juiz, vislumbrando uma lacuna legislativa, se utiliza desse aspecto para suprir a omissão de forma aparente a criar um novo precedente.

Percebe-se que o juiz poderia ter decidido utilizando o direito posto, e a isso se inclui as normas, jurisprudências, súmulas e demais outros tantos aparatos que lhe valem; no entanto, inova no ordenamento jurídico, o que em palavras simples se traduz na conclusão de que o magistrado se portou como legislador positivo, matéria típica do Poder Legislativo, órgão político e representado democraticamente por cidadãos eleitos.

Tipicamente cabe ao Poder Legislativo a inegável garantia constitucional de editar leis. O Brasil encontra-se doutrinariamente num país "codicístico", no qual se vê a grande necessidade de edição de normas para fundamentar uma situação, como se isso fosse garantir ao cidadão sua mais grandiosa "justiça".

Nesse sentido, o ativismo judicial ultrapassaria os limites impostos pela Constituição Federal, adentrando na esfera do Legislativo, perfazendo um conflito jurisdicional. Assim, "os juízes não são eleitos, bem como não são responsáveis perante os eleitores, como ocorre com os legisladores, logo não poderiam criar leis" (ABREU, 2013, p. 229).

Nesse ínterim, com o ativismo judicial e o Poder Legislativo, surge o conflito existencial, se o Poder Judiciário, ao inovar no ordenamento jurídico brasileiro, estaria legislando, infringindo e suprimindo o princípio da separação dos poderes descrito explicitamente no artigo 2ำ da Constituição Federal. Relatando opiniões sobre o assunto:

O magistrado, por vezes, ao realizar sua tarefa exegética, exerce atividade típica de um legislador (sem o ser), suprindo as lacunas da lei e recheando-as com elementos mais humanos e garantidores da plena realização da justiça. Quando nos referimos ao ativismo judicial, não há porque se falar em ofensa à separação dos poderes estatais, em que tal ativismo seja exercido com respeito às regras e princípios constitucionais. Ao contrário do que se possa parecer, este fenômeno hermenêutico, inerente do Poder Judiciário, passa, pouco a pouco a 
ser ferramenta fundamental para harmonização dos poderes, reforçando a previsão constitucional, gerando reciprocidade e fortalecendo o elo pacificador e necessário entre as funções políticas estatais (CAMARGO; DOMINGOS, 2012, p. 72).

Sobre o crescimento atual do ativismo judicial, percebe-se que uma das primeiras e principais causas é a inércia e/ou ineficácia do Poder Legislativo no cumprimento de suas atribuições típicas. $\mathrm{O}$ ativismo judicial tem como causa a prática ou abstenção do poder político legiferante em sua atuação. Diante dessa premissa, o cidadão, necessitando ter acesso a normas mais contemporâneas, busca, por meio do Poder Judiciário, as soluções de suas controvérsias.

\begin{abstract}
Assim, na democracia, uma lei somente pode deixar de ser aplicada em seis hipóteses [...]: (a) quando a lei for inconstitucional, aplicando-se os mesmos mecanismos de controle de constitucionalidade; (b) na hipótese em que, na relação texto e norma, for cabível uma interpretação conforme a Constituição; (c) quando for caso de nulidade parcial sem redução de texto; (d) quando se tratar de resolução pelo critério das antinomias - com os devidos cuidados, é claro; (e) quando for caso de inconstitucionalidade parcial com redução de texto e (f) quando for uma hipótese de uma regra se chocar com um princípio constitucional, claro que com os cuidados relacionados ao pamprincipiologismo. Fora dessas hipóteses, se o julgador quiser elaborar uma nova lei - $e$ digo isso com toda a lhaneza e respeito - deve se candidatar a uma vaga no Parlamento. Simples, pois (STRECK, 2015, p. 162) (Grifo nosso).
\end{abstract}

Fatores positivos e negativos no aspecto teórico sobre o ativismo judicial sempre irão surgir. Colocar um freio no Poder Judiciário engessaria algumas questões suplicadas pela população. É nessa perspectiva que a avaliação da representatividade política no direito brasileiro torna-se um fator primordial para a continuidade da presente pesquisa.

\title{
3 A REPRESENTATIVIDADE POLÍTICA NO DIREITO BRASILEIRO COMO GARANTISMO DEMOCRÁTICO
}

A ideia de representatividade política começa a ter maior ímpeto na modernidade a partir da passagem do regime monárquico para uma soberania popular, quando a classe burguesa batalhou por seus direitos perante o rei, visando, assim, a uma derrocada nos Estados Absolutistas. Assim, "é neste contexto, que um novo significado de representação adquire um papel essencial no esboço de reestruturação do espaço do Político, devidamente adequado às novas exigências impostas pela forma de reprodução social da modernidade" (VIEIRA, 2006, p. 21).

Atualmente, a representatividade política no Direito Brasileiro é classificada como indireta e nomeada cláusula pétrea, sendo devidamente prevista no artigo 60, § 4으, da Constituição Federal, qual seja, "não será objeto de deliberação a proposta de emenda tendente a abolir o voto direto, secreto, universal e periódico" (BRASIL, 1988). Complementando o dispositivo, resta inferir que "todo o poder emana do povo, que o exerce por meio de representantes eleitos ou diretamente" (BRASIL, 1988).

Desta forma, fica claramente evidente que o povo será representado politicamente por cidadãos eleitos democraticamente, que fazem parte de instituições políticas que são encarregadas de administrar os entes federativos a fim de garantir os direitos e deveres democráticos de todos. Resumidamente, "a representação democrática é autorização outorgada pelo povo a um órgão soberano, institucionalmente legitimado pela constituição, para agir autonomamente em nome do povo e dos interesses destes" (SOARES, 2011, p. 234).

Há muito vêm se falando, entretanto, sobre uma determinada crise de representatividade política que se alarma no regime democrático não somente brasileiro, mas sendo esse um fenômeno mundial. Conforme disposto anteriormente, a forma representativa democrática é cláusula pétrea, não havendo possibilidade de mudanças por meio de emenda constitucional. O que se questiona na atualidade, porém, são as péssimas escolhas políticas que acarretam uma degringolada frustração social.

O voto, sendo este um sufrágio universal e direito de todos os cidadãos, salvo os constitucionalmente dispensados e/ou impedidos, antes considerados uma forma de mudança e orgulho, modernamente é algo desacreditado e uma possibilidade de barganha para alguns brasileiros. A crise na representatividade política faz decair o sentimento democrático de maior amplitude numa nação, qual seja, a possibilidade de transformações iminentes e claras no país por intermédio de um direito amplo amparado constitucionalmente. 
Mediante a crise de representatividade política, o próprio regime democrático tem sido constantemente questionado. Conforme disposto, "a Democracia é o direito positivo de qualquer pessoa - qualquer pessoa representa 'o povo' e deverá ser tratada de modo que o Estado possa ser legitimamente qualificado de 'democrático'” (MULLER, 2013, p. 111).

Como o poder encontra-se nas mãos de poucos e estes por inércia, omissão ou "jogada política", não são ativos legislativamente, prolifera assim a atuação crescente do Poder Judiciário. Desta forma, o regime democrático brasileiro tem se revelado de forma excludente e limitadora a determinados grupos (elites) que atingiram o ápice do poder político, o qual foi determinante para a continuidade desse poderio por vários mandatos e inúmeras gerações vindouras. Fica claro que tais elites possuem o espírito democrático, porém não são compostas para beneficiar a população.

De outro lado, a mesma crise de representatividade política tem implicações sociais. Num país fadado a injustiças e corrupções, e onde o assunto corriqueiro tornou-se o "mensalinho", "mensalão", lava a jato e delação premiada, a população sente-se desamparada diante a ausência de poderes ou órgãos que lhe garantam seus mínimos direitos. É assim que o Poder Judiciário, não obstante também praticar alguns atos criticáveis, ainda é visto como uma chance de consolidar que o direito ande juntamente com os anseios da sociedade.

Nessa visão inconstante de uma democracia representativa que claramente não representa politicamente o povo, é que o Poder Judiciário se sobressai dando um amparo social ante a inércia e/ou omissão dos Poderes Políticos que, teoricamente, deveriam garantir à população em geral suas perspectivas constitucionais.

"Povo" nunca deve funcionar como metáfora. O povo sempre deve aparecer como sujeito político empírico, inclusive na esfera da Justiça. O conceito aqui elaborado não necessita de um "povo" como expressão que não obriga a nada e cobre tudo; ele não necessita de nenhuma "vontade geral" que não se deixasse verificar e identificar na política empírica; mas, pelo contrário, de um povo que possa, no plano das instituições, efetivamente entrar em cena como destinatário e agente de controle e de responsabilidade: eleição/destituição do mandato por votação, bem como votação livre como componente democrático do cerne da Constituição (MULLER, 2013, p. 110).

A crise da representatividade no Direito Brasileiro trouxe à tona o tema-chave discutido no presente artigo, sendo esse a possibilidade de o Poder Judiciário ter voz e vez perante os Poderes Legislativo e Executivo que possuem a representatividade democrática, sendo estes os representantes do povo e para o povo. Deste modo, até mesmo a forma democrática é questionada: Que democracia é esta quando o regime descrito pelo país não coaduna com os princípios constitucionalmente nele inseridos? Nessa perspectiva, Soares (2011) descreve que "o regime democrático deve propiciar oportunidade para todos, em uma conquista cotidiana" (p. 240).

Percebe-se, desta forma, que a crise na representatividade política se encontra atrelada a uma crise democrática. A democracia participativa, constitucionalmente prevista, deu lugar a grandes grupos que se instituíram ao poder e nele continuam por longos anos sem questionamentos ou manifestações populares. Alguns partidos, após graves escândalos, obtiveram baixas na popularidade, porém resta claro que os mesmos ainda continuam dentre os partidos que mais detêm orçamentos.

Lamentavelmente, o discurso constitucional, que sustenta o Estado democrático de direito brasileiro, é uma utopia, distante da realidade constitucional, a qual apresenta instituições políticas carcomidas pela ineficiência e pela corrupção, conspurcando o processo democrático. Os costumes excludentes dos segmentos privilegiados do povo brasileiro, ao englobar sua mentalidade e seus valores, se opõem à igualdade política e à igualdade de condições dignas de vida.

$[\ldots]$

A democratização do Brasil depende, nesse sentido, das possibilidades de mudanças nos costumes e nas mentalidades de classe dominante em uma sociedade estigmatizada pela experiência do mando, do favor, da exclusão e do privilégio (SOARES, 2011, p. 241).

Resta inferir que a representatividade política é causa e consequência direta da participação popular. Infelizmente o Brasil é moldado por cidadãos que barganham sua supremacia universal do voto por favores políticos. Enquanto o cidadão atuar direta e indignamente em prol de seus interesses, tal continuísmo será proliferado e constante. 


\section{O ATIVISMO JUDICIAL: RUPTURA À DEMOCRÁTICA REPRESENTATIVIDADE POLÍTICA BRASILEIRA?}

Percebe-se, atualmente, uma tendência excessiva no enaltecimento do Poder Judiciário com a capacidade de resolução de toda e qualquer questão, o que retira das esferas Legislativas e Executivas as suas típicas competências. A população, por dúvida ou questionamento da capacidade do Poder Legislativo, inclina-se a judicializar a matéria.

Essa exponencial idealização de que o Poder Judiciário é o centro da resolução de conflitos acaba por retirar do Poder Legislativo o que Ihe fora dado pelo regime democrático de direito por meio do voto popular como representante da população.

Em razão de tais críticas, a sua aplicação no Brasil implicará a aceitação de ativismo judicial nefasto, que mascara arbitrariedades judiciais consubstanciadas na imposição do ponto de vista dos juízes sobre quais valores substantivos sejam mais adequados para que a comunidade política alcance a justiça e a igualdade social. Tal conduta, sem sombra de dúvida, promoverá o esvaziamento funcional da atividade parlamentar, em prejuízo da manifestação da vontade popular na tomada de decisões fundamentais para a sociedade, através do debate público (SOUZA; GOMES, 2015, p. 125).

Assim, a discussão sobre determinadas questões passa do Poder Legislativo, em que há um processo democrático da representatividade do povo, para o Poder Judiciário, principalmente pelo Supremo Tribunal Federal, magistrados não eleitos. O debate posto em xeque, então, é realizado de forma única, exclusiva e irrecorrível pelo órgão máximo do Poder Judiciário.

Uma crítica a ser exposta, portanto, é o fato de o Supremo Tribunal Federal (STF), órgão judicial, realizar atribuições que regem o país sem a devida representatividade política para tanto. Nestes termos, "juízes, desembargadores e ministros - não são agentes públicos eleitos. Embora não tenham o batismo da vontade popular, magistrados e tribunais desempenham, inegavelmente, um poder político, inclusive o de invalidar atos dos outros dois Poderes" (BARROSO, 2012a, p. 27-28).

Comumente é vista a interferência do Poder Judiciário em anular atos típicos dos Poderes Legislativo e Executivo. Nesta perspectiva, o órgão máximo judicial está realizando um ato eminentemente político e, assim, surge a teoria denominada "dificuldade contramajoritária" (BARROSO, 2012b, p. 12). O que se resume no contexto exposto é: os agentes políticos, devidamente eleitos democraticamente pelo voto popular, têm seus atos cassados por um Poder Judicial em que os membros não políticos exercem a função não por vontade do povo, o que contraria a democracia representativa garantida pela Constituição Federal.

Thamy Pogrebinschi (2012) conceitua o contramajoritarismo sobre aspectos críticos, e dispõe que são "aqueles nos quais o STF não apresenta preocupação em preservar a vontade majoritária expressa na norma legislada pelo Parlamento, porém, ao contrário, em nome da guarda da Constituição, não se intimida em fazer substituir a vontade do legislador pela sua" (p. 120).

Claramente no que fora dito, o Supremo Tribunal Federal pode anular os atos dos outros poderes; no entanto, nenhum órgão é falível de erros. Quem, portanto, cassaria as decisões errôneas proferidas pelo órgão maior? A supremacia do Poder Judiciário pode ir de encontro com a vontade popular mediante a representatividade dos membros políticos devidamente eleitos? Uma decisão do poder político, democraticamente representantes do povo, pode ser invalidada por um órgão não representativo?

Várias críticas e inúmeras indagações são apontadas nas doutrinas atuais sobre o assunto ativismo judicial e suas incongruências democráticas. O STF, neste cenário, torna-se um órgão hegemônico e soberano passando por cima de toda a democracia alcançada por meio do voto popular. Assim, "nunca é demais lembrar que o poder emana do povo, não dos juízes" (BARROSO, 2012b, p. 16).

A acessibilidade dos indivíduos, que deveria ser por intermédio dos representantes políticos eleitos, estaria sendo violada por meio da usurpação do Poder Judiciário ante o Poder Legislativo, infringindo o regime democrático. A questão levada a juízo e não ao Legislativo passa a responsabilidade ao magistrado, que age em nome da coletividade. 
Os juízes não devem criar novo direito, mas aplicar o direito já criado por outras instituições. Embora tal assertiva seja o ideal a ser perseguido, muitas vezes, na prática, não pode ser plenamente concretizada. [...] Os juízes, portanto, seja de forma dissimulada ou explícita, às vezes, devem criar um novo direito. Quando assim agem, na verdade, devem agir como se fossem delegados do Poder Legislativo, pois devem solucionar o caso concreto da maneira que o legislador promulgaria uma lei caso estivesse diante desse problema. Ou seja, os juízes criam leis, em resposta a fatos e argumentos, da mesma natureza daqueles que levariam o Poder Legislativo a criar, caso estivesse agindo por iniciativa própria. Entretanto, na realidade, os juízes não são legisladores delegados e eles não legislam quando vão além das decisões políticas já tomadas por outras pessoas (ABREU, 2013, p. 228-229).

No mais, os juízes possuem a capacidade teórico-jurídica sobre uma questão, não portando o entendimento técnico, econômico, científico e outros específicos de determinadas áreas (multidisciplinaridade), o que faz com que os resultados das decisões sejam imprevisíveis, configurando-se uma insegurança jurídica.

O magistrado normalmente não possui capacidade que não seja a jurídica. Outros profissionais de áreas específicas possuem conhecimento maior em determinada questão discutida. Sendo assim, na maioria das vezes o magistrado necessita de um apoio técnico para a resolução de um problema. É o que dispõe acertadamente o trecho a seguir:

O juiz, por vocação e treinamento, normalmente estará preparado para realizar a justiça do caso concreto, a microjustiça. Ele nem sempre dispõe das informações, do tempo e mesmo do conhecimento para avaliar o impacto de determinadas decisões, proferidas em processos individuais, sobre a realidade de um segmento econômico ou sobre a prestação de um serviço público. Tampouco é passível de responsabilização política por escolhas desastradas (BARROSO, 2012b, p. 16).

Não se está afirmando, neste contexto, que o Poder Legislativo teria melhores condições de resolver uma matéria do que o Poder Judiciário. Afirma-se, no entanto, que o Legislativo está legitimamente amparado pelo processo democrático representativo, o que daria condão de avaliar melhor a questão visando o interesse da população em geral, não intentando somente os aspectos jurídicos do fato.

O Supremo Tribunal Federal não representa democraticamente a população. Os Poderes Legislativo e Executivo (órgãos políticos) sim, possuem a representatividade eletiva. Se, portanto, a democracia advém da representatividade, o ativismo judicial (devidamente realizado pelo Poder Judiciário) é, em determinados termos, antidemocrático.

A Constituição Federal de 1988 deixou claro o regime adotado por uma democracia representativa, em que o mandato político é outorgado pelo povo por meio do voto universal, direto e secreto. É o que dispõe o parágrafo único do primeiro artigo, relatando que "todo o poder emana do povo, que o exerce por meio de representantes eleitos ou diretamente" (BRASIL, 1988). Desta forma, os magistrados não representam democraticamente a população, e dar este poder a eles, por intermédio do ativismo judicial, ultrapassa o modelo democrático representativo.

Outro enfoque necessita, entretanto, ser realizado. A exponencial judicialização é um fator diretamente relacionado à inércia e/ou omissão do Poder Legislativo e, desta forma, configura uma crise de representatividade. A delegabilidade do Poder Legislativo em suas funções típicas em detrimento do Poder Judiciário, pressupõe uma falta de compromisso com o seu próprio labor e uma insuficiente vontade política.

Os assuntos levados ao Poder Judiciário são, em regra, de relevância ímpar e com opiniões destoantes pelas mais diversas classes sociais. Deixar o problema para que o Poder Judiciário encontre uma decisão, portanto, exime o Poder Legislativo de embates junto a população. O que se percebe é que essas demandas são complexas, críticas e enfrentam opiniões divergentes. Por esperteza ou por uma simples jogada política, provocar o Poder Judiciário para decidir sobre a matéria tira um fardo do Poder Legislativo.

[...] Certos temas envolvem questões polêmicas e, por terem um custo político muito alto para quem toma determinada posição sobre a matéria, não são decididas pelos Poderes Executivo e Legislativo de forma proposital, já que estes têm receio da reação da opinião pública. Isto posto, essa inércia deliberada acaba, muitas vezes, levando ao Poder Judiciário, que não depende da vontade dos eleitores, a missão de solucionar tais questões (FERNANDES; NELSON, 2014, p. 461). 
Em muitos casos o que se vislumbra é que existem projetos de leis tramitando sobre as mais diversas matérias acerca de assuntos delicados que envolvem religião, moral, fatores econômicos, sociais e, por que não, íntimos e, nestes casos, o Poder Legislativo cumpre um posicionamento esquivando-se de legislar. $\mathrm{Na}$ sequência, o Poder Judiciário é provocado e, como não pode se eximir de deliberar, como fazem os demais Poderes políticos, inova criativamente no ordenamento.

Este ciclo vicioso entre ativismo judicial e sua causa possui reação imediata na crise de representatividade. $O$ ativismo existe por inatividade dos parlamentares em eximir-se de discutir assuntos que possam impactar categoricamente em sua posição política numa possível reeleição.

Destarte, para boa parte dos membros das duas Casas do Poder Legislativo, mais do que o desinteresse de legislar em relação a certos temas, existe, na verdade, o interesse em não legislar; interesse em evitar temas polêmicos em que a assunção de determinada posição pode afastar parcela de votos do eleitorado que o elegeu. E, no sistema proporcional, onde poucos candidatos ultrapassam o quociente eleitoral, cada voto é importante. Essa omissão consciente do Poder Legislativo é denominada, por alguns autores, de "delegação estratégica" (de questões polêmicas) ao Poder Judiciário (RAMOS; OLIVEIRA JÚNIOR, 2014, p. 38-39).

Infelizmente, a causa descrita como crise de representatividade é dos cidadãos. É pelo ato democrático do voto que a população escolhe os seus representantes políticos. Se existe uma crise, inércia, ócio, apatia ou "esperteza política" para que os projetos de leis fiquem adormecidos até que o Poder Judiciário seja provocado a decidir, o problema está no momento de eleger os representantes.

Referidas pesquisas e reflexões apontam para o perigo que o ativismo judicial representa para a representação política, até porque uma ofensa à Constituição por parte do Poder Judiciário sempre é mais grave do que qualquer outra deferida por qualquer dos outros Poderes, porque é ao Judiciário que cabe sua guarda. Quem nos salvará se não há mais salvadores? Ou pior: quem nos salvará dos salvadores? (STRECK, 2014, p. 164).

Certamente a questão em análise é levada ao Poder Judiciário principalmente pelo fator celeridade o que é discutível tendo em vista a demanda excessiva que abarrota o órgão. Mesmo assim, é pelo motivo temporal que várias matérias são judicializadas, pleiteando por uma tramitação processual mais ágil do que o seria por meio do procedimento legislativo, estigmatizando ainda mais este órgão perante a população.

Outra consideração a ser apontada é que, havendo o ativismo judicial, realizado pelo STF, existe a possibilidade de erro. O Pretório Excelso não é um órgão soberano imune de falhas e, caso ocorra, a nova regra terá eficácia até que o mesmo órgão mude o entendimento. Resumidamente, mesmo havendo um possível erro no ativismo realizado pelo órgão máximo, os Poderes Legislativo e Executivo não têm a competência para retirar a regra.

Na verdade, o STF vem assumindo o perfil de um verdadeiro Tribunal Constitucional, mais preocupado em resolver grandes questões do país, e, por isso, passou a indicar qual é o direito a ser aplicado mesmo na falta de leis. O problema é saber justamente se a Constituição outorga esse poder ou se ele foi criado pelo próprio STF. $O$ certo é que existe essa tendência no Tribunal, e, pelos últimos julgamentos da Corte, pode-se concluir que é uma tendência irreversível, a curto prazo (MEDEIROS, 2013, p. 207).

Conforme explanado em alguns momentos, a Constituição Federal é extensa e prolixa. O mesmo acontece com as legislações em vigor, tendo vista a gama de leis e, com isso, a grande possibilidade de o magistrado utilizar aquela norma ou outra a depender do caso concreto. Neste ínterim é que se origina a discricionariedade jurídica do magistrado, dando ao mesmo a oportunidade de escolha da legislação adequada ao fato.

Resta ainda inferir que, quando o Poder Judiciário emprega o ativismo judicial criativamente e inova no ordenamento jurídico, dando sentido outro ao texto constitucional, acaba por violar o Poder Constituinte Originário, que é o responsável pela criação da Constituição Federal regente de todo o sistema jurídico brasileiro.

Quando determinada questão chega ao STF para que o mesmo desenvolva uma resolução sobre o aparente problema, este o deve fazer de forma a interpretar conforme a Constituição Federal. $O$ impasse encontra-se mesmo na interpretação do tribunal e, por isso, tantas discordâncias dentro de um mesmo órgão. Assim, citamos Lenio Luiz Streck (2014), que, de forma jocosa, relata: "a Constituição é aquilo que o STF diz que é" (p. 141). 
Pensando friamente sobre o assunto, o dito autor foi muito feliz na sua exposição. Como o surgimento do ativismo judicial realizado pelo STF, em sua maioria, advém de provocações por meio de Ações Diretas de Inconstitucionalidade (ADIs), o órgão máximo acaba sendo a ultima ratio na decisão sobre a interpretação de determinado assunto descrito na Constituição Federal. Assim, além de guardião da Constituição, o Pretório Excelso é o enunciador da interpretação a ser dada a ela.

Há que se destacar o entendimento do Supremo Tribunal Federal quanto ao ativismo judicial e à participação proativa em prol de um senso comum com a possibilidade de interpretação criativa e inovadora, quando lhe for provocado a julgar matéria de cunho social, moral e político, características que se enquadram no processo de judicialização e, em razão da forma de julgar, adentram na esfera ativista. Tal orientação do órgão de cúpula do Poder Judiciário pode ser retirada do julgamento da ADI 1.351-3/DF, no voto do ministro Gilmar Ferreira Mendes sobre o tema crítico que decidiu sobre a filiação partidária, no que passa a expor:

Portanto, é possível antever que o Supremo Tribunal Federal acabe por se livrar do vetusto dogma do legislador negativo e se alie à mais progressiva linha jurisprudencial das decisões interpretativas com eficácia aditiva, já adotadas pelas principais Cortes Constitucionais europeias. A assunção de uma atuação criativa pelo Tribunal poderá ser determinante para a solução de antigos problemas relacionados à inconstitucionalidade por omissão, que muitas vezes causam entraves para a efetivação de direitos e garantias fundamentais assegurados pelo texto constitucional (STF. ADI 1.351-3/DF, Relator: Min. Marco Aurélio, p. 145. Tribunal Pleno. Data de Julgamento, 7/12/2006. DJ 30/3/2007).

Em artigo intitulado Supremocracia, nome bastante sugestivo, Oscar Vilhena Vieira (2008) destaca a expansão exponencial do Pretório Excelso e dos tribunais em geral ante o parlamento, colocando aquela Corte no centro do sistema político brasileiro. Na descrição do artigo citado, o autor explana que, com a ampliação de seus poderes, o órgão máximo do Poder Judiciário, em suas decisões, substitui as escolhas majoritárias que deveriam ser exercidas por órgãos representativos de natureza democrática (VIEIRA, 2008, p. 441-464).

Esse sintoma de ser tudo levado a soluções do Supremo Tribunal Federal, reflete uma crise de representatividade já anteriormente descrita. A tendência em judicializar matérias políticas é uma forma de deixar claro que os outros Poderes estão aquém de suas principais atribuições. Desta forma, a população se vê acuada quanto à falta de garantias mínimas e recorre ao Poder Judiciário como uma salvaguarda de seus direitos.

\section{CONSIDERAÇÕES FINAIS}

De tudo o que foi exposto, a carência da população em ter representantes políticos ativos com vontade de contribuir e realizar suas funções de forma proba , traz uma sobreposição do Poder Judiciário, que se transforma em um salvador da sociedade ao garantir o mínimo de direitos descrito na Constituição Federal. Desse modo, o Judiciário assume um valor mais elevado, haja vista a deficiência dos outros Poderes, havendo, assim, uma ligação direta entre o exacerbado ativismo judicial e a crise de representatividade política.

Os críticos ao ativismo judicial reconhecem um Supremo Tribunal Federal altamente proativo, que se atribui de funções legislativas e perpassa os limites primários descritos na Constituição Federal. De outro lado, os defensores do Instituto relatam ser o ativismo judicial um fato concreto, tendo em vista a omissão dos outros Poderes ao não reagirem às implicações sociais. Assim, o Poder Judiciário seria a ultima ratio na possibilidade de os cidadãos garantirem seus direitos.

Tristemente, em vários momentos os poderes políticos têm sua atuação desaprovada. Tal crítica é correta, uma vez que, num país fadado a injustiças, corrupção, utilização de verba pública em benefício próprio e outros tantos desgostos vislumbrados cotidianamente, a população sente-se desamparada ante a ausência de Poderes ou órgãos que lhe garantam seus mínimos direitos. Neste caso, o Poder Judiciário, não obstante também praticar alguns atos criticáveis, ainda é visto como uma chance de garantia da consolidação de direitos previstos no ordenamento jurídico.

Diante da inércia dos poderes políticos, a judicialização transformou-se numa alavancada possibilidade de a população fazer parte do sistema, trazendo como efeito o abarrotamento dos órgãos com ações e recursos repetitivos, pleitos desnecessários e subsunção de custo elevado ao Estado em razão da alta carga processual, quando não há servidores suficientes para suprir a demanda. Se, entretanto, o elevado ativismo judicial é a ultima ratio, tendo em vista a apatia política, a demora legislativa e a carência de bons representantes -e 
que este seja realizado com probidade e segurança e, por fim, que garanta igualdade de tratamento processual, celeridade no procedimento e acesso ao Poder Judiciário a todos que dele suplicarem por preservação de garantias - este encontra-se escasso.

Ainda é cedo para afirmar qual o rumo do ativismo judicial e suas consequências diante da inércia política, porém não é possível imiscuir do julgamento e, nesta ocasião, a proatividade do Judiciário acode no presente momento os anseios por justiça.

\section{REFERÊNCIAS}

ABREU, João Paulo Pirôpo de. A autonomia financeira do Poder Judiciário: limites traçados pelo princípio da independência e harmonia dos poderes. Brasília: Centro de Estudos Judiciários, 2013.

BARROSO, Luis Roberto. Judicialização, ativismo judicial e legitimidade democrática. Revista [Syn]Thesis, Rio de Janeiro, v. 5, n. 1, p. 23-32, 2012a. Disponível em: https://www.e-publicacoes.uerj.br/index.php/synthesis/article/view/7433. Acesso em: 9 abr. 2021.

BARROSO, Luís Roberto. Constituição, democracia e supremacia judicial: direito e política no Brasil contemporâneo. RFD - Revista da Faculdade de Direito - UERJ, v. 2, n. 21, jan./jun. 2012b. Disponível em: https://www.e-publicacoes.uerj.br/index.php/ rfduerj/article/view/1794/2297. Acesso em: 9 abr. 2021.

BRASIL. Constituição da República Federativa do Brasil de 1988. Diário Oficial da União, Brasília, 5 out. 1988. Disponível em: http://www.planalto.gov.br/ccivil_03/constituicao/ConstituicaoCompilado.htm. Acesso em: 19 mar. 2019.

BRASIL. Supremo Tribunal Federal. ADI 1.351-3/DF. Partido político - funcionamento parlamentar - propaganda partidária gratuita - fundo partidário [...] Tribunal Pleno. Rel. Min. Marco Aurélio. Diário de Justiça Eletrônico, 30 mar. 2007. Disponível em: https://stf.jusbrasil.com.br/jurisprudencia/758756/acao-direta-de-inconstitucionalidade-adi-1351-df/inteiro-teor-100474925?ref=juris-tabs. Acesso em: 19 mar. 2019.

CAMARGO, Daniel Marques de; DOMINGOS, Fernanda Cristina Rosseto. Ativismo Judicial: limites, possibilidades e reflexos na efetivação de direitos humanos fundamentais. In: SIQUEIRA, Dirceu Pereira; SANTOS, Murilo Angeli Dias dos (org.). Estudos contemporâneos de hermenêutica constitucional. São Paulo: Editora Boreal, 2012. p. 67-85.

FERNANDES, Rafael Laffitte; NELSON, Rocco Antonio Rangel Rosso. O Supremo Tribunal Federal e o ativismo judicial: (re)analisando o dogma do "legislador negativo". Revista Eletrônica Direito e Política, Itajaí: Programa de Pós-Graduação Stricto Sensu em Ciência Jurídica da Univali, v. 9, n. 1, p. 450-476, quadrimestre de 2014. Disponível em: https://siaiap32.univali.br/seer/ index.php/rdp/article/download/5763/3140. Acesso em: 19 mar. 2019.

FERNANDES, Ricardo Vieira de Carvalho. Ativismo judicial: por uma delimitação conceitual à brasileira. Revista Confluências, Niterói, v. 12, n. 2, p. 106-128, out. 2012. Disponível em: https://www.confluencias.uff.br/index.php/confluencias/article/viewFile/121/145. Acesso em: 20 mar. 2019.

MEDEIROS, Orione Dantas de. O controle de constitucionalidade na Constituição brasileira de 1988. Do modelo híbrido à tentativa de alteração para um sistema misto complexo. Revista de Informação Legislativa, a. 50, n. 200, p. 189-210, out./dez. 2013. Disponível em: https://www2.senado.leg.br/bdsf/bitstream/handle/id/502943/000991834.pdf?sequence=1. Acesso em: 19 mar. 2019.

MULLER, Friedrich. Quem é o povo? 7. ed. São Paulo: Editora Revista dos Tribunais, 2013.

RAMOS, Paulo Roberto Barbosa; OLIVEIRA JUNIOR, Jorge Ferraz de. Características do ativismo judicial nos Estados Unidos e no Brasil. Um breve histórico do ativismo judicial na Suprema Corte Norte-Americana e um paralelo com o recente ativismo judicial da Suprema Corte brasileira. Revista de Informação Legislativa, v. 51, n. 204, p. 25-42, out./dez. 2014. Disponível em: http://www2.senado.leg.br/bdsf/item/id/509926. Acesso em: 19 mar. 2019.

POGREBINSCHI, Thamy. Judicialização ou representação? Política, Direito e Democracia no Brasil. Rio de Janeiro: Elsevier, 2012. SOARES, Mário Lúcio Quintão. Teoria do Estado. Novos paradigmas em face da globalização. 4. ed. São Paulo: Editora Atlas, 2011.

SOUZA, Isabella Saldanha de; GOMES, Magno Federici. Ativismo judicial, democracia e sustentabilidade. Rio de Janeiro: Lumen Juris, 2015.

STRECK, Lenio Luiz. Compreender Direito. Como o senso comum pode nos enganar. São Paulo: Editora Revista dos Tribunais, 2014. V. 2.

STRECK, Lenio Luiz. Jurisdição constitucional e decisão jurídica. 3. ed. São Paulo: Editora Revista dos Tribunais, 2013.

STRECK, Lenio Luiz. Compreender Direito. Nas brechas da lei. São Paulo: Editora Revista dos Tribunais, 2015. V. 3.

VIEIRA, Oscar Vilhena. Supremocracia. Revista Direito GV, São Paulo, p. 441-464, jul./dez. 2008. Disponível em: http://www. scielo.br/pdf/rdgv/v4n2/a05v4n2.pdf. Acesso em: 19 mar. 2019. 